\title{
Veno-venous ECMO for carbon dioxide removal in a neonate after Norwood operation with an RV-PA shunt
}

\author{
Tomasz Mroczek, Jerzy Jarosz, Wojciech Stycuła, Monika Miklaszewska, Miroława Dudyńska, \\ Janusz Hieronim Skalski
}

Department of Paediatric Cardiac Surgery, Jagiellonian University Collegium Medicum, Krakow

Kardiochirurgia i Torakochirurgia Polska 2013; 10 (2): 165-167

\begin{abstract}
We describe a case of a newborn with a single-ventricle congenital heart defect, in which veno-venous extracorporeal membrane oxygenation (ECMO) was successfully employed shortly after a Norwood operation with right ventricle-to-pulmonary artery shunt due to pulmonary insufficiency.

Key words: veno-venous ECMO, Norwood operation.
\end{abstract}

\section{Introduction}

The strategy of employing extracorporeal membrane oxygenation (ECMO) in the management of infants with a single ventricle and a systemic-to-pulmonary shunt is controversial and associated with a high percentage of failures [1]. In congenital heart surgery, the use of ECMO may result from a number of indications, including preoperative support, failure to wean from cardiopulmonary bypass (CPB), cardiac arrest, low cardiac output, and severe hypoxia [2]. In this study, we report a successful application of veno-venous ECMO (VV ECMO) support in a neonate after a Norwood operation with an RV-to-PA shunt procedure performed due to pulmonary insufficiency.

\section{Case description}

The $3.05 \mathrm{~kg}$ boy, born at the gestational age of 40 weeks, was noted to be tachypneic, cyanotic, and presenting with a heart murmur. Echocardiographic examination revealed mitral atresia, double outlet right ventricle, subaortic and aortic valve stenosis, restrictive patent foramen ovale, mild hypoplasia of the distal arch, coarctation of the aorta, and patent ductus arteriosus. Mechanical ventilatory support and continuous prostaglandin $E_{1}$ infusion were initiated. The patient underwent balloon atrial septostomy and, at the age of 19 days, he was subjected to a Norwood pro-

\section{Streszczenie}

W pracy opisano przypadek noworodka z wrodzoną wadą serca o typie pojedynczej komory serca, u którego we wczesnym okresie po operacji sposobem Norwooda z zespoleniem prawa komora-tętnica płucna zastosowano z powodzeniem żylno-żylne pozaustrojowe wspomaganie układu oddechowego (extracorporeal membrane oxygenation - ECMO).

Słowa kluczowe: ECMO żylno-żylne, operacja Norwooda.

cedure with the placement of a $5 \mathrm{~mm}$ right ventricle to pulmonary artery (RV-to-PA) shunt. Because of enhanced hypoxia and secondary hemodynamic instability, cardiac catheterization was performed on day 3 after the operation. Angiography did not show any obstruction of either the RV-to-PA graft or the pulmonary arteries; however, an exceptionally long arterial phase with diastolic recoil into the central pulmonary arteries was detected, suggesting elevated pulmonary vascular resistance. The filling of the pulmonary veins was delayed; however, blood flow to the left atrium, which appeared to empty normally, was visible. Balloon atrial septostomy was performed to completely exclude the possibility of left atrial outlet obstruction. However, hypoxemia and hypercarbia persisted and were unresponsive to several methods of mechanical ventilation, as well as nitric oxide administration. Respiratory acidosis intensified, with the arterial partial pressure of carbon dioxide $\left(\mathrm{PaCO}_{2}\right)$ above $80 \mathrm{~mm} \mathrm{Hg}$ and arterial partial pressure of oxygen $\left(\mathrm{PaO}_{2}\right)$ oscillating at about 20 $\mathrm{mm} \mathrm{Hg}$. A decision was made to employ ECMO support. As there were no symptoms of low cardiac output or primary ventricular dysfunction, VV ECMO was employed. The right internal jugular vein was accessed percutaneously, and a $10 \mathrm{~F}$ venous cannula was introduced and advanced into the right atrium. Veno-venous ECMO was initiated by

Address for correspondence: dr hab. med. Tomasz M. Mroczek, Department of Paediatric Cardiac Surgery, Jagiellonian University Collegium Medicum, Wielicka 265, 30663 Kraków, +48 6013322 17, e-mail: t_mroczek@hotmail.com 
withdrawing blood from the right atrium and infusing it through a femoral venous $5 \mathrm{~F}$ catheter. A standard ECMO circuit set was employed. Continuous heparin sodium infusion was used in order to maintain the activated clotting time at 180-200 s. The flow rate at the beginning of the support, which was $35 \mathrm{ml} / \mathrm{kg} / \mathrm{min}$, was gradually reduced to $15 \mathrm{ml} / \mathrm{kg} / \mathrm{min}$, and then to $7 \mathrm{ml} / \mathrm{kg} / \mathrm{min}$ shortly before the cessation of ECMO. The VV ECMO was continued for 9 days. After the introduction of ECMO, the child's hemodynamic status stabilized, confirming the hypothesis of a pulmonary cause of the instability. A "lung protection strategy" was applied by means of reducing the ventilation setup from synchronized intermittent mechanical ventilation (SIMV) 35/min, PIP $41 \mathrm{~mm} \mathrm{Hg}$, positive end-expiratory pressure (PEEP) $6 \mathrm{~mm} \mathrm{Hg}$, tidal volume (TV) $75 \mathrm{ml}$, fraction of inspired oxygen $\left(\mathrm{FiO}_{2}\right) 1.0$ to SIMV 20/min, peak inspiratory pressure (PIP) $33 \mathrm{~mm} \mathrm{Hg}$, PEEP $1 \mathrm{~mm} \mathrm{Hg}$, TV $60 \mathrm{ml}$, $\mathrm{FiO}_{2}$ 0.5. Fluctuations of blood gas values are presented in Fig. 1 . The $\mathrm{pO}_{2}$ value was low, but $\mathrm{pCO}_{2}$ was controllable and was maintained within the normal range. Urine output was satisfactory, and no neurological sequelae attributable to ECMO were observed. During the extracorporeal support, the patient was receiving antibiotic treatment due to Escherichia coli bacteremia and radiological symptoms of pneumonia. After weaning from ECMO, the patient demonstrated continued respiratory disability, received positive pressure ventilation/mechanical ventilatory support for 25 days, and was discharged 42 days after the operation with systemic oxygen saturation of $71-80 \%$ in room air.

\section{Discussion}

The ECMO in neonates with single-ventricle defects is applied due to low cardiac output, cardiac arrest, or ventricular dysfunction after surgical procedures [3, 4]. We have described a rare situation in which ECMO support was applied due to pulmonary insufficiency of unclear cause, most likely a combination of high pulmonary vascular resistance and pneumonia. Usually, ECMO support in neonates after Norwood procedures is performed by means of AV ECMO; therefore, reports concerning $\mathrm{VV} \mathrm{CO}_{2}$ removal in neonates with single-ventricle physiology are rare. The use

systemic $\mathrm{PaO}_{2}$ and $\mathrm{PaCO}_{2}$ on VV EMCO

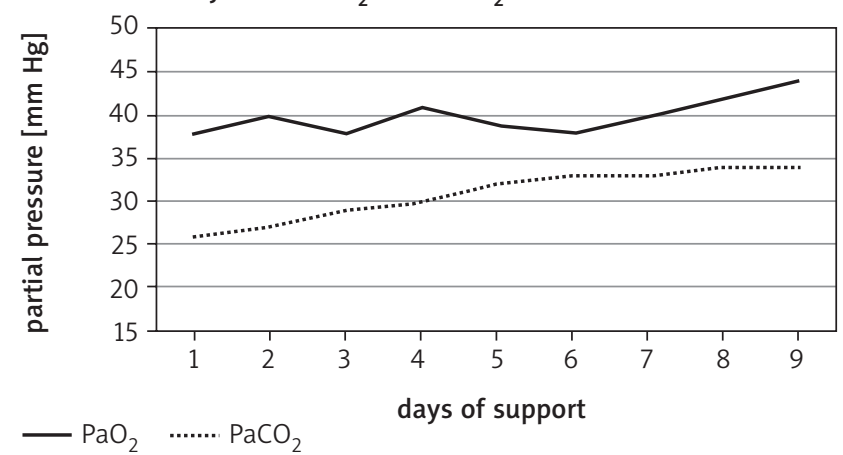

Fig. 1. Partial pressure of $\mathrm{Pa}_{2}$ and $\mathrm{PaCO}_{2}$ during ECMO support in neonate after Norwood with RV-PA conduit of extracorporeal life support (ECLS) in patients after Norwood procedures, who constitute a particularly challenging subgroup with reportedly poorer overall outcomes, continues to raise controversy [5]. The lower survival rate in these patients has been partially attributed to an imbalance between systemic and pulmonary perfusion and its associated impact on coronary perfusion due to the diastolic run-off into the pulmonary bed [6]. The replacement of the classic systemic-to-pulmonary shunt with an RV-toPA shunt eliminates the dilemma related to the selection of shunt management strategy during ECMO. Additionally, the better hemodynamic conditions offered by this type of shunt may allow for less hemodynamically invasive ECLS in the form of VV ECMO for pulmonary insufficiency.

Veno-venous ECMO is an alternative to veno-arterial bypass that provides pulmonary gas exchange, but no direct cardiac support. Hypoxia and acidosis, as well as the increased mean intrathoracic pressure, resulting from the ventilatory strategies used to maintain oxygenation, decrease cardiac output and tissue oxygen delivery. The improved venous blood oxygenation and lower airway pressure achieved with VV ECMO have substantially improved cardiac function in our patient, as well as allowing for a reduction of the possible "volume and pressure trauma" for his lungs [7].

Some additional potential advantages of $\mathrm{V}$ bypass are: sparing the carotid artery from ligation and keeping the chest closed (only a venous access is necessary), maintaining a normal pulsatile blood flow pattern, and maintaining pulmonary flow with oxygenated blood, which may decrease pulmonary vascular resistance. Veno-venous ECMO provides a more stable hemodynamic situation in comparison to AV support and does not radically change the Qp/Qs ratio.

Veno-venous ECMO is possible with percutaneous access only, with easy bleeding control and reduced circuit installation time. In our case, the size of the cannulas was appropriate to maintain $\mathrm{PaCO}_{2}$ in the normal range. Recent neonatal studies have shown that AV and VV ECLS support are clinically equivalent in terms of outcome in similar neonatal patients with severe respiratory failure [8]. In older children, double-lumen cannulas may facilitate rapid percutaneous establishment of VV ECMO.

The separation of pulmonary and cardiac support in this "physiologically challenged" population of patients makes the VV ECMO technique easy to control, and provides mechanical ventilatory management similar to the standard technique, while preventing damage to the diseased lung by reducing the setup parameters. Cannulation of the right atrium and femoral vein may decrease the "recirculation effect".

Veno-venous ECMO after Norwood operation with RVPA shunt may be especially recommended for treating pulmonary disturbances, including pulmonary hypertension and pneumonia (e.g. viral).

In conclusion, the survival of patients with a single ventricle after Norwood procedures with RV-to-PA shunts may be improved by VV ECMO support. 


\section{References}

1. Jaggers JJ, Forbess JM, Shah AS, Meliones, JN, Kirshbom PM, Miller CE, Ungerleider RM. Extracorporeal membrane oxygenation for infant postcardiotomy support: significance of shunt management. Ann Thorac Surg 2000; 69: 1476-1483.

2. Cooper DS, Jacobs JP, Moore L, Stock A, Gaynor JW, Chancy T, Parpard M, Griffm DA, Owens T, Checchia PA, Thiagarajan RR, Spray TL, Ravishankar C.Cardiac extracorporeal life support: state of the art in 2007. Cardiol Young 2007; 17 Suppl 2: 104-115.

3. Pizarro C, Davis DA, Healy RM, Kerins PJ, Norwood WI. Is there a role for extracorporeal life support after stage I Norwood? Eur J Cardiothorac Surg 2001; 19: 294-301.

4. Imamura M, Schmitz ML, Watkins B. et al. Venovenous extracorporeal membrane oxygenation for cyanotic congenital heart disease. Ann Thorac Surg 2004; 78: 1723-1727.
5. Sherwin ED, Gauvreau K, Scheurer MA, Rycus PT, Salvin JW, Almodovar MC, Fynn-Thompson F, Thiagarajan RR. Extracorporeal membrane oxygenation after stage 1 palliation for hypoplastic left heart syndrome. J Thorac Cardiovasc Surg 2012; 144: 1337-1343

6. Malec E, Januszewska K, Kolcz J, Mroczek T. Right ventricle-to-pulmonary artery shunt versus modified Blalock-Taussig shunt in the Norwood procedure for hypoplastic left heart syndrome - influence on early and late haemodynamic status. Eur J Cardiothorac Surg 2003; 23: 728-734.

7. Ryan LP, Montenegro LM, Bird GL, Gruber PJ. Successful support and separation from veno-venous extracorporeal membrane oxygenation support in a three-month-old patient following bidirectional Glenn procedure. Interact Cardiovasc Thorac Surg 2010; 11: 496-498.

8. Keckler SJ, Laituri CA, Ostlie DJ, St Peter SD. A review of venovenous and venoarterial extracorporeal membrane oxygenation in neonates and children. Eur J Pediatr Surg 2010; 20: 1-4 